\title{
Creative Legal Study among Undergraduate Medical Students: Sharing Technique from Mae Fah Luang University
}

Arnon Jumlongkul ${ }^{1}$

Address: ${ }^{1}$ School of Medicine, Mae Fah Luang University, Chiang Rai, Thailand 57100

E-mail: arnon.jum@mfu.ac.th

ORCID number of the corresponding author: https://orcid.org/0000-0002-4333-7186

\section{Declarations}

Funding: Any financial supports were provided by Mae Fah Luang University.

Conflicts of interest/Competing interests: Not applicable.

Availability of data and material: Not applicable.

Code availability: Not applicable.

Authors' contributions: Not applicable.

Ethics approval: Not applicable.

Consent to participate: I, Dr. Arnon Jumlongkul, hereby declared that I participated in this work solely.

Consent for publication: I, Dr. Arnon Jumlongkul, give my consent for the publication of all identifiable details within this article.

\begin{abstract}
In Thailand, the topic of medical ethics and laws related to medical professions has been one part of the national competency assessment criteria. The objective of this article was to design legal issues into the medical curriculum and to share experiences of creative legal study. Legal contents were inserted into 10 subjects and taught for year 1 to year 6 medical students. Students were divided into multi-groups or received individual tasks and then, shared their knowledge and idea for solving legal problems. The results showed they could interpret and create novel ideas for legal and ethical reconstruction, including the topic of the principle of laws, criminal laws, civil and commercial laws, public health laws, organ donation/transplantation, end of life decisions, and legal liability for the medical profession. Finally, the creative legal study can be used as a novel approach to support creativity among medical students.
\end{abstract}

Keywords: Creative legal study; creativity; medical curriculum; medical student

\section{Introduction}

Nowadays legal study is one of the most important subjects in medical schools. The legal and moral issues were introduced by the Hippocratic Oath, which has been in existence since $400 \mathrm{BC}$ from the father of medicine, namely "Hippocrates". The commitment such as the prohibition of abortion and euthanasia was declared within this oath. In 1500, the University of Wittenberg, a German medical school, amalgamated taking this oath for graduate medical students. The oath became universal in the early $19^{\text {th }}$ century. In 1948, the World Medical Association (WMA) in Geneva, Switzerland, adopted it to the Declaration of Geneva, and then it was rewritten in 1964 and was applied by the American Medical Association (AMA) as well as many US medical schools. However, for each country, the oath is not a portion of laws but also it is only an ethical signpost (Hajar, 2017; Indla \& Radhika, 2019). 
The relationship between laws and medicine has been incorporated with medical education. In the United States, medical students are usually exposed to a class of medical jurisprudence, regulatory issues in medicine as well as legal pitfalls in practice since the first-year course (Shah, 2008). In the United Kingdom, the General Medical Council (GMC) has stated that teaching medical ethics and law should establish one of the core contents of a medical curriculum. In 1998, a core topic list for medical ethics and law included informed consent and refusal of treatment, clinical relationship, confidentiality, medical research, human reproduction, new genetics, children, mental disorders and disabilities, life-death-dying and killing, vulnerabilities, resource allocation, and rights (Doyal \& Gillon, 1998) whilst it was revised and added some issues in 2010, for example, professionalism, beginning of life, towards the end of life, justice and public health, foundations and medical ethics and law, capacity and incapacity (Wong \& Balasingam, 2013).

In Thailand, the Medical Council of Thailand (TMC) has performed as a medical regulator that can operate physicians' behaviors in accordance with the Medical Professional Act B.E. 2525 (1982). It also announced the Medical Competency Assessment Criteria for National License B.E. 2555 (2012) which was separated into 5 sections, especially Section 4 - medical ethics, and Section 5 - laws related to medical professions. In general, a medical curriculum in Thailand has used a 6-year based training program. However, as part of Section 5, there is a lack of recommendation for what does a topic should be taught for year one or year six students. Moreover, traditional legal subjects for undergraduate students have usually involved the part of recognition and interpretation without creativity supports. Then the objective of this article was to design legal issues incorporated with the medical curriculum and to share experiences of creative legal study among undergraduate medical students.

\section{Methods}

This article presented an alternative legal teaching method that needed students to describe their ideas to clean up some legal and ethical issues related to physicians and health care personnel. According to Section 5 of the Medical Competency Assessment Criteria for National License B.E. 2555, the author then divided all legal contents into the 6 -year medical curriculum that is shown in Table 1. Some parts of ethical issues in Section 4 were incorporated with legal issues. Basically, easy contents were proposed for the pre-clinical year (year 1-3) whereas the clinical year students (year 4-6) then learned special laws and ethics. The author, who graduated with the Master of Laws, Doctor of Medicine, and the Diploma of the Thai Board of Forensic Medicine, taught all displaying contents solely. The number of students in each class was mainly 32 persons. All issues have been taught from the academic year 2018 to the present.

For each class, medical students received handouts and questions that they might prepare before the class. All students were then divided into multi-groups or took their individual responsibility. Questions consisted of four levels, including remembering, understanding, applying, and creativity. They then shared their knowledge and idea for solving legal problems.

\begin{tabular}{|c|l|l|l|}
\hline Class & \multicolumn{1}{|c|}{ Subject } & \multicolumn{1}{|c|}{ Legal study topic } & \multicolumn{1}{c|}{ Ethical study topic } \\
\hline Year 1 & Professional Development 1 & $\begin{array}{l}\text { - The Constitution of the } \\
\text { Kingdom of Thailand B.E. 2560 } \\
\text { - Principle of laws for physicians }\end{array}$ & - Declaration of patient's rights \\
\hline Year 2 & Professional Development 2 & $\begin{array}{l}\text { - Basic of criminal laws } \\
- \text { Public health laws for } \\
\text { physicians }\end{array}$ & \\
\hline Year 3 & Professional Development 3 & $\begin{array}{l}- \text { Basic of civil and commercial } \\
\text { laws }\end{array}$ & \\
& & $\begin{array}{l}\text { - Public health laws for } \\
\text { physicians (cont.) }\end{array}$ & \\
\cline { 2 - 5 } & Reproductive System 2 & - Criminal laws - sexual assault & \\
\cline { 2 - 5 } & Urinary System 2 & $\begin{array}{l}\text { - Criminal and civil laws related } \\
\text { to organ donation }\end{array}$ & $\begin{array}{l}\text { - Ethics of transplantation/organ } \\
\text { donation }\end{array}$ \\
\hline
\end{tabular}




\begin{tabular}{|l|l|l|l|}
\hline & $\begin{array}{l}\text { Principle of Pathology and } \\
\text { Forensic Medicine }\end{array}$ & $\begin{array}{l}\text { - Civil procedure laws - expert } \\
\text { and witness }\end{array}$ & \\
\hline Year 4 & Professional Development 4 & $\begin{array}{l}\text { - Criminal laws - specific } \\
\text { offences and petty offences }\end{array}$ & \\
\hline Year 5 & Professional Development 5 & $\begin{array}{l}\text { - Laws related public health } \\
\text { personnel } \\
\text { - Criminal laws - specific } \\
\text { offences (cont.) }\end{array}$ & $\begin{array}{l}\text { - End of life decisions } \\
\text { - Legal liability for medical } \\
\text { profession }\end{array}$ \\
\hline Year 6 & $\begin{array}{l}\text { Community, Family and } \\
\text { Occupational Medicine 5 }\end{array}$ & $\begin{array}{l}\text { - Medical laws related to welfare } \\
\text { and protection of rights }\end{array}$ & \\
\cline { 2 - 5 } & $\begin{array}{l}\text { Emergency and Forensic } \\
\text { Medicine 2 } 2 \text { Criminal procedure laws - } \\
\text { ordinary proceedings of inquiry } \\
\text { Criminal procedure laws - post } \\
\text { mortem inquest }\end{array}$ & \\
\hline
\end{tabular}

Table 1. The legal study incorporated with the 6-year medical curriculum

\section{Results}

For each topic, medical students could interpret and create novel ideas for legal reconstruction. The instances of students' suggestions for legal and ethical considerations, which were separated into eight groups, are shown as follows;

\subsection{Principle of laws}

Opinions from the first-year medical students, the academic year 2020, also included, firstly, nowadays some legal sections may demoralize the country, then the authority should revise and amend the old laws following the dynamic of society. Secondly, some government sectors, as well as government officers, have made the distinction between people, therefore, transparency is one of the most important things of modern organizations. Thirdly, justice has been driven slowly whereas the cost of justice is too high. The authority should support the efficacy of the administrative system as well as reject any ridiculous legal procedures. Finally, some government officers have made their benefits using the gap of law. Students thought that we must find that legal gap and plug it.

\subsection{Criminal laws}

The fourth-year medical students, the academic year 2020, suggested the way to develop the Thai criminal laws, including the inspection and revision of all Thai laws which are out-of-date, making concise laws that almost people can comprehend easily, creating laws base on justice and the benefit of majority citizen, and the suggestion of legal amendment by an independent legislative organization that is the fast track to propose any special issue, which is ignored by the parliament.

In the sexual assault session, the third-year medical students, the academic year 2020, described the result of sexual crime that affected the country into four aspects, including politics, economics, society, and the public health system. They proposed the way to prevent the occurrence of sexual harassment, for example, the government and academic institute should induce the campaign and advertisement involving how to prevent an individual from the crime event, the training of martial art for vulnerable groups, and find the way, not only to prevent but also to remedy both victims and criminals before returning them to their community.

\subsection{Civil and commercial laws}

Opinions from year 2 students, the academic year 2020, was that a healthcare service should be one part of the contracts for work because of the previous judgment of the supreme court. Then if physicians make any medical malpractice or medical negligence, they should be punished according to the Civil and Commercial Code. To prevent this worst situation, medical personnel must treat their patients following standard medical guidelines. 


\subsection{Public health laws}

The second-year medical students, the academic year 2020, shared their ideas about the Narcotics Drug Act B.E. 2522 that the defensive measure of the spread of narcotic plants (e.g. marijuana, hemp, Korth) should be concerned about the restriction of use because they have pharmaceutical properties as well as the role of addictive substances.

\subsection{Organ donation/transplantation}

The third-year medical students, the academic year 2020, discussed that the process of organ donation and transplantation has been covered by the Organ Donation Center of the Thai Red Cross Society and the Medical Council of Thailand. Some issues that they concerned also included the training of a transparent coordinator who will inform and educate the relatives of the brain death donor, preparing of the logistic system when the death occurs, and the avoidance of organ transplantation within the private health sector to prevent an economic disparity between the rich and poor people.

\subsection{End of life decisions}

Students from year 5, the academic year 2020, showed their opinions that the law enforcement in Thailand, which relates to euthanasia, has been covered by the Constitution of the Kingdom of Thailand B.E. 2560, the criminal code as well as the National Health Act B.E. 2550, Section 12, which only the right to make a living will to refuse the public health service but also it does not involve the right to make active euthanasia. They thought this topic correlated to both criminal laws and ethical considerations. To solve this ambiguous problem, the government should enact a specific law that is based on the moral, ethical, and religious aspects of the Thai people.

\subsection{Legal liability for the medical profession}

The fifth-year medical students, the academic year 2020, told that today there is no specific law for applying to a medical case. Then an alternative justice, including the mediation, arbitration, diversion, and the suspension of prosecution should be used for physicians. They preferred a mediator helping negotiation between medical personnel and injured persons using restorative justice.

\section{Discussion and Conclusions}

The creative legal study seems to be a novel approach to support creativity among medical students. One consideration of this technique is that almost all students were not familiar with a discussion that needed their ideas to solve the legal problems. Some undergraduate medical learners said he or she had never learned in this style before. Some questions, such as either "In your opinion, what is an appropriate method for designing our health policy?" or "How to develop our country following your way?", are scarcely among medical schools. The author found sometimes no one shared their idea or even receiving a question from students. They asked the author that "How should I reply to your question? I think it has no absolute answer". The challenge of this technique is to reset the students' perception from the knowledge receiver to be the policymaker. One method that could support the discussion environment is to assign the discussion issues before a class or keep score during their argument. Eventually, in the future, the author hopes all medical students will become good healthcare leaders who can design health policies that ground on the understanding of the legal system.

\section{Acknowledgements}

All financial and facility supports were provided by Mae Fah Luang University. The author would like to thank my lovely medical students who gave me the most value of teaching experiences. 


\section{References}

Doyal, L., \& Gillon, R. (1998). Medical ethics and law as a core subject in medical education. BMJ, 316(7145), 16231624. https://doi.org/10.1136/bmj.316.7145.1623

Hajar, R. (2017). The physician's oath: Historical perspectives. Heart Views, 18(4), 154. https://doi.org/10.4103/HEARTVIEWS.HEARTVIEWS_131_17

Indla, V., \& Radhika, M. S. (2019). Hippocratic oath: Losing relevance in today's world? Indian Journal of Psychiatry, 61(Suppl 4), S773-S775. https://doi.org/10.4103/psychiatry.IndianJPsychiatry_140_19

Shah, N. D. (2008). The Teaching of Law in Medical Education. AMA Journal of Ethics, 10(5), 332-337. https://doi.org/10.1001/virtualmentor.2008.10.5.oped1-0805

Wong, R. S. Y., \& Balasingam, U. (2013). Teaching Medical Law in Medical Education. Journal of Academic Ethics, 11(2), 121-138. https://doi.org/10.1007/s10805-013-9184-9 